Plant Production Science

Available online at http://zjar.journals.ekb.eg

http:/www.journals.zu.edu.eg/journalDisplay.aspx?.Journalld=1\&queryType=Master

\title{
IMPACT OF FOLIAR AND SOIL FERTILIZATION ON PRODUCTIVITY AND QUALITY OF SOME SOYBEAN CULTIVARS UNDER CALCAREOUS SOIL CONDITIONS
}

\author{
Engy S.M.R. Abo Zahra ${ }^{1}$, Mary E.Nashed ${ }^{1}$, Seham M. Mohamed ${ }^{1}$ and Salwa M.A. \\ Ash-Shormillesy $^{2}$
}

1. Crop Physiol. Dept., Agric. Res. Cent., Egypt

2. Agron. Dept., Fac. Agric., Zagazig Univ., Egypt

Received: 01/04/2020 ; Accepted: 20/07/2020

\begin{abstract}
A field experiment was conducted at Nubaria Agricultural Research Station Farm, Alexandria, Egypt, during 2015 and 2016 summer seasons to evaluate the efficiency of three fertilization treatments (i.e. $\mathrm{T}_{1}$ : recommended dose of soil fertilizers of $48 \mathrm{~kg} \mathrm{~N} / \mathrm{ha}+72 \mathrm{~kg} \mathrm{P}_{2} \mathrm{O}_{5} / \mathrm{ha}$ and $57.6 \mathrm{~kg} \mathrm{~K} 2 \mathrm{O} / \mathrm{ha}, \mathrm{T}_{2}: 50 \%$ of the previous recommended dose of $24 \mathrm{~kg} \mathrm{~N} / \mathrm{ha}+36 \mathrm{~kg} \mathrm{P}_{2} \mathrm{O}_{5} / \mathrm{ha}$ and $28.8 \mathrm{~kg} \mathrm{~K}_{2} \mathrm{O} /$ ha with foliar application of phosphoric acid $(0.025 \%)$ and potassin $(1.8 \mathrm{ppm}) . \mathrm{T}_{3}$ : foliar application of phosphoric acid $(0.025 \%)$ and potassin $(1.8 \mathrm{ppm})$ only) on growth, productivity and quality of three soybean cultivars, Giza 21, Giza 22 and Giza 111. The results revealed significant differences among studied cultivars in crop growth rate, chlorophyll content, plant height, number of branches/plant, number of pods/plant, 100-seed weight, seed yield/ha, oil and protein yields/ha, Seed oil (\%), seed protein content, seed phosphorus (\%), seed potassium (\%), straw nitrogen (\%), straw phosphorus (\%) and straw potassium (\%) in both seasons and their combined analysis with superiority of Giza 111 in all studied traits followed by Giza 21, while Giza 22 recorded the lowest values for such traits except plant height, where Giza $22 \mathrm{cv}$ gave the tallest plants $(115.1 \mathrm{~cm})$. Differences due to fertilization treatments were significant for all studied traits, where $T_{2}$ treatment $(50 \%$ of the recommended dose of $\mathrm{N}, \mathrm{P}$ and $\mathrm{K}+$ phosphoric acid and potassin) outperformed the other treatments followed by $T_{1}$ treatment, while the $T_{3}$ treatment gave the lowest values. The interaction between cultivars and fertilization treatments significantly influenced on No. of branches/plant, chlorophyll content and seed oil (\%) in the first season and seed phosphor (\%) in both seasons. In general, the highest value of seed yield/ha was obtained from Giza 111 cultivar meanwhile, the treatment of $50 \%$ recommended dose of $\mathrm{N}, \mathrm{P}$ and $\mathrm{K}+$ phosphoric acid and potassin gave also the best seed yield/ha. Seed yield (ton/ha), was positively and significantly correlation with each of number of branches/plant $\left(0.834^{*}\right)$, number of pods/plant $\left(0.956^{* *}\right), 100$ - seed weight $(0.824 *)$, oil yield (ton /ha) $(0.954 * *)$, protein yield (ton/ha) $\left(0.988^{* *}\right)$ and cholorophyll content $\left(0.965^{* *}\right)$.
\end{abstract}

Key words: Soybean, cultivars, NPK, phosphoric acid and potassin.

\section{INTRODUCTION}

Soybean (Glycine max) is a plant species belonging to the legume family. Soybean is classified as an oilseed and has been used as food and industrial crops globally. It is distinct from other types of pulses as it contains eight essential amino acids necessary for the human body to make protein. This makes it an excellent source of complete protein, especially for vegetarians. In Egypt, the decrease in the area and production in the last twenty years due to competition with other strategic summer crops on the limited cultivated area and higher production costs with lower net income which related to marketing problems and the damage

Corresponding author: Tel.: +201202521986

E-mail address: dr.salwaalymani@gmail.com 
resulted from leaf feeding insects. So, increasing the production for such crop is a main goal. This could be achieved via cultivating high yielding cultivars combined with application appropriate cultural practices (El-Karamity et al., 2015).

Several studies aimed to measure the performance of new released high yielding soybean cultivars. In this concern, significant differences in yield and yield components were detected among soybean cultivars including Giza 21, Giza 22, Giza 35, Giza 81, Giza 111 and Crawford (El Haggan and Mekkei, 2014; El-Karamity et al., 2015).

Fertilization is one of the most important factors limiting productivity of plants. N, P and $\mathrm{K}$ are essential nutrients and important for plant growth and development. The most important role of $\mathrm{N}$ in plant is its presence in the structure of protein and nucleic acids, which are the most important building and genetic substances of every cell. In addition, $\mathrm{N}$ is also found in chlorophyll that enables the plant to transfer sunlight energy to food by photosynthesis. Thus, $\mathrm{N}$ supply to the plant will influence the amount of protein, amino acids, protoplasm and chlorophyll formation. Moreover, it influences the cell size, leaf area and photosynthetic activity (Diacono et al., 2013; Piccinin et al., 2013). On the other hand, phosphorus is an important nutrient for all crops in general and legumes in particular. It is considered an essential component of ATP (adenosine triphosphate) and plays an important role in energy and cell biosynthetic processes also in different roles in seed formation. Phosphorus application for soybean is essential, since it enhances the growth of root system and increases oil percentage of soybean seeds, consequently increasing the productivity of this crop. Although, the phosphorus content in the Egyptian soil is high, the available phosphorus is too low to face the plant requirements(Devlin and Witham, 1983). Therefore, Ibrahim (2014) reported that, increasing phosphorus fertilizer levels from 15.5 to $31 \mathrm{~kg} \mathrm{P}_{2} \mathrm{O}_{5} /$ fad., increased plant height, number of branches, pods and seeds per plant, seed yield/ plant and fad., 100seed weight and protein (\%), while oil (\%) was decreased.

In addition, $\mathrm{K}$ has a beneficial effect on $\mathrm{N}$ fixation and the transformation of photosynthetic products from leaves to root nodules (Savani $\boldsymbol{e t}$ al., 1995). The intensive use of expensive mineral fertilizers in recent years results on environmental pollution problems. However, chemical fertilizers at extremely high rates for along period decreased the potential activity of microflora and the stability of soil organic matter (Hussein, 1995). Therefore, this study was designed to investigate the impact of reducing soil fertilization of N,P and $\mathrm{K}$ - levels and spraying with phosphoric acid and potassin on productivity and quality of some soybean cultivars.

\section{MATERIALS AND METHODS}

\section{Site Description and Soil Analysis}

The present investigation was conducted at Nubaria Agricultural Research Station Farm, Alexandria Egypt, during the two successive summer seasons of 2015 and 2016 to study the effect of three fertilization treatments on growth, productivity and quality of three soybean cultivars, under surface ordinary irrigation system.

The preceding crop was wheat in both seasons. A brief information concerning some physical and chemical properties of the experimental site are given determined according to Klute (1986) in Table 1.

\section{Studied Factors and Experimental Design}

The experiment included nine treatments which were the combination of three soybean cultivars (Giza 21, Giza 22 and Giza 111), and three fertilization treatments as following, $\mathrm{T}_{1}$ : soil fertilization with recommended dose of mineral fertilizers i.e. $48 \mathrm{~kg} \mathrm{~N} / \mathrm{ha}+72 \mathrm{~kg} \mathrm{P}_{2} \mathrm{O}_{5} / \mathrm{ha}$ and $57.6 \mathrm{~kg} \mathrm{~K}$ O/ha, $\mathrm{T}_{2}: 50 \%$ of the previous

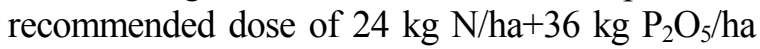
and $28.8 \mathrm{~kg} \mathrm{~K} \mathrm{~K}_{2} \mathrm{O} / \mathrm{ha}$ with foliar application of phosphoric acid $(0.025 \%)$ and potassin (1.8 ppm) and $\mathrm{T}_{3}$ : foliar application only with phosphoric acid $(0.025 \%)$ and potassin (1.8 ppm).

The experimental design was split-plot in four replications in each season. Soybean cultivars were allocated to the main plots and the three fertilizer treatments were randomly distributed at the sub plots. Seeds of soybean were obtained from Legume Crops Department, Field Crops Research Institute, Giza, Egypt. 
Table 1. Soil mechanical and chemical analyses of the experimental site (for the upper 0-30 cm depth)

\begin{tabular}{|c|c|c|}
\hline Soil analyses & $1^{\text {st }}$ season & $2^{\text {nd }}$ season \\
\hline \multicolumn{3}{|c|}{ Soil mechanical analysis } \\
\hline Sand $(\%)$ & 54.93 & 54.89 \\
\hline Clay $(\%)$ & 14.96 & 15.30 \\
\hline Silt (\%) & 30.11 & 29.81 \\
\hline Soil texture & Sandy loam & Sandy loam \\
\hline \multicolumn{3}{|l|}{ Soil chemical analysis } \\
\hline Organic matter (\%) & 0.21 & 0.19 \\
\hline $\mathrm{CaCO}_{3}(\%)$ & $22-71$ & $23-12$ \\
\hline Soil EC (ds/m) & 1.83 & 1.92 \\
\hline $\mathbf{P}^{\mathrm{H}}$ & 8.29 & 8.26 \\
\hline \multicolumn{3}{|c|}{ Soluble cations (meg/ l) } \\
\hline $\mathbf{C a}^{++}$ & 4.11 & 4.73 \\
\hline $\mathbf{M g}^{++}$ & 1.40 & 1.47 \\
\hline $\mathrm{Na}^{+}$ & 9.86 & 10.12 \\
\hline $\mathbf{K}^{+}$ & 2.93 & 2.88 \\
\hline \multicolumn{3}{|l|}{ Soluble anions meg/ l } \\
\hline $\mathrm{CO}_{3}{ }^{=}$ & -- & -- \\
\hline $\mathrm{HCO}_{3}^{-}$ & 1.97 & 1.42 \\
\hline $\mathrm{Cl}^{-}$ & 10.34 & 11.62 \\
\hline $\mathrm{SO}_{4}$ & 5.99 & 6.16 \\
\hline Available $\mathbf{N}$ & 34.42 & 38.71 \\
\hline Available P & 3.29 & 3.30 \\
\hline Available K & 112.3 & 103.41 \\
\hline
\end{tabular}

The mineral fertilizers, were applied as ammonium sulphate $(20.5 \% \mathrm{~N})$, calcium super phosphate $\left(15.5 \% \mathrm{P}_{2} \mathrm{O}_{5}\right)$ and potassium sulphate $\left(48 \% \mathrm{~K}_{2} \mathrm{O}\right)$. Nitrogen chemical fertilizer was applied in two doses, i.e. $25 \%$ from the dose was added after sowing and $75 \%$ was supplied 30 days after sowing. Whereas, phosphorus and potassium fertilizer rates were applied just one dose at sowing. Plants were sprayed two times with phosphoric acid and potassin at vegetative stage (30 and 45 days after sowing). The experimental plot area was $10.8 \mathrm{~m}^{2}(3.60 \mathrm{~m} \mathrm{x} 3$ $\mathrm{m})$ with six ridges, the distance between ridges was $60 \mathrm{~cm}$ and $10 \mathrm{~cm}$ between hills, Plants were thinned to secure two plants per hill after full germination. Treatments were sprayed by hand sprayer. Soybean seeds were inoculated before sowing with Bradyrizobium Japonicum (mixture of several active strains) obtained from Agricultural Research Center.
Sowing dates were 21 and 18 May in the first and second seasons, respectively. Other cultural practices for growing soybean were conducted as recommended.

\section{Data Measurement}

\section{Growth analyses}

At various growth stages, three samples were recorded at 55, 70 and 85 days after planting. In each sample, ten individual plants were hand pulled randomly from the second ridge, the samples were oven dried at $70^{\circ} \mathrm{C}$ for 48 hours to constant weight to record the total dry weight / plant. Crop growth rate (CGR) of soybean plants was calculated using the following formula mentioned by Watson (1952). Crop growth rate (CGR), $\mathrm{g} / \mathrm{m}^{2} /$ week $=\mathrm{W}_{2}-\mathrm{W}_{1 /}\left(\mathrm{t}_{2}-\mathrm{t}_{1}\right) \mathrm{A}$

Where:

$\mathrm{W}_{1}$ and $\mathrm{W}_{2}$ plant dry weight at time $\mathrm{t}_{1}$ and $\mathrm{t}_{2}$. 
A, ground area occupied by plants $\left(\mathrm{m}^{2}\right)$

At $90^{\text {th }}$ day, after planting total cholorophyll content of leaves $\left(\mathrm{mg} / \mathrm{m}^{2}\right)$ was determined as SPAD unit using SPAD502 apparatus (Soil and Plant Analysis Department) of Minolta Co. This units were transformed to $\mathrm{mg} / \mathrm{m}^{2}$ as describted by Monje and Bugbee (1992) as follows:

$$
\mathrm{chl}=80.05+10.4(\text { SPAD502) }
$$

\section{Yield and yield components}

At harvest time, 10 plants were randomly pulled from the third ridge of each plot to estimate,Plant height, number of branches/plant, number of pods/plant and 100-seed weight . Meanwhile, seed, biological and straw yields/ha, where calculated on the basis of the three ridges from each experimental plot, then converted into ton/ha.

\section{Quality traits}

Seed oil (\%), was determined by using the Soxhelt continuous extraction apparatus according to AOAC (1980). Seed and straw N (\%) were estimated by applaying the modified Kjeldahel's method according to AOAC (1980). Seed protein content was calculated by multiplying total nitrogen by 6.25 . After seed oil and protein content determinations, registered oil yield/ha (ton) by multiply the seed yield/ha (ton) by its seed oil content and dividing by 100 , and Protein yield (ton /ha), was calculated by multiplying the crude protein content by seed yield/ha (ton) and dividing by 100 . Seed and straw $\mathrm{P}(\%)$, samples of seeds and straw were digested by $\mathrm{HNO}_{3}, \mathrm{H}_{2} \mathrm{SO}_{4}$ and $\mathrm{HClO}_{4}(10: 1: 4$ $V / V / V)$ and re-evaporated, the $\mathrm{P}$ concentration in digests was estimated at $460 \mathrm{~nm}$ using molybdenum ascorbic acid method (Murphy and Riley, 1962). Seed and straw K (\%), were determined using flame photometer as described by Jackson (1967).

\section{Statistical Analysis}

Data were analyzed with the appropriate method of statistical analysis of variance (ANOVA) as described by Gomez and Gomez (1984) by using MSTAT-C software, and means were compared using the least significant differences test (LSD) at 0.05 level of probability. Meanwhile, the combined analysis was performed for data of the two seasons after the homogeneity test of error by Bartlet's test (Steel and Torrie 1980). Simple correlation coefficient was calculated between seed yield/ha and all the other components by using the data of combined analysis.

\section{RESULTS AND DISCUSSION}

Results presented in Tables 2, 3, 4 and 5 show the effects of levels and different sources of N,P and $\mathrm{K}$ on growth, productivity and chemical analysis of some soybean cultivars.

\section{Growth Analysis}

\section{Effect of cultivars on crop growth rate and chlorophyll content}

Results presented in Table 2 generally show that that there were significant differences among the three soybean cultivars in both seasons and combined analysis. Regarding to the combined analysis, the three soybean cultivars inherently varied in their mean values of CGR and chlorophyll content. Hassaan and Bughdady (2018) observed the sesame cultivars variation respecting chlorophyll content, since the cultivar Giza 111 attained the highest values followed by Giza 21 and Giza 22 . In CGR this trend holds fairly true at the two growth periods in both seasons and combined analysis.The results observed by Ash-Shormillesy (2001) on flax confirmed that there were differences between cultivars in CGR. The cultivar behaviour in such aforementioned growth parameters may reflect the variation in the genetical make up of tested cultivar as well as the interaction with the environmental conditions prevailing in the experimental area

\section{Effect of fertilization treatments on crop growth rate and chlorophyll content}

Regarding fertilizer treatment effects, results in Table 2 show that the three fertilization treatments were significantly different in their estimates of CGR and chlorophyll content, where the $\mathrm{T}_{2}$ fertilization treatment exhibited the greatest values followed by $T_{1}$ and $T_{3}$, respectively. Here, the effect of $T_{2}$ treatment of fertilization on the CGR during the two growing periods is clear, these results are in agreement 
Zagazig J. Agric. Res., Vol. 47 No. (4) 2020

Table 2. Crop growth rate $\left(\mathrm{g} / \mathrm{m}^{2} /\right.$ week) and Chlorophyll content $\left(\mathrm{mg} / \mathrm{m}^{2}\right)$ of soybean as affected by different treatments during 2015 and 2016 seasons

\begin{tabular}{|c|c|c|c|c|c|c|c|c|c|}
\hline \multirow[t]{2}{*}{ Treatment } & \multicolumn{3}{|c|}{$\begin{array}{l}\text { Crop growth rate } \\
\text { (55-70 days) }\end{array}$} & \multicolumn{3}{|c|}{$\begin{array}{c}\text { Crop growth rate } \\
\text { (70-85 days) }\end{array}$} & \multicolumn{3}{|c|}{$\begin{array}{l}\text { Chlorophyll } \\
\text { content }\end{array}$} \\
\hline & 2015 & 2016 & Comb. & 2015 & 2016 & Comb. & 2015 & 2016 & Comb. \\
\hline \multicolumn{10}{|l|}{ Cultivars: $\mathrm{V}$} \\
\hline Giza 111 & 1.41 & 1.35 & 1.38 & 1.06 & 1.05 & 1.06 & 431.3 & 426.0 & 428.7 \\
\hline Giza 21 & 1.29 & 1.29 & 1.29 & 0.94 & 0.90 & 0.92 & 411.2 & 406.4 & 408.8 \\
\hline Giza 22 & 1.25 & 1.20 & 1.23 & 0.86 & 0.83 & 0.85 & 376.7 & 376.8 & 376.7 \\
\hline F. test & $*$ & $*$ & $*$ & $*$ & $*$ & $*$ & $*$ & $*$ & $*$ \\
\hline LSD at0.05 & 0.053 & 0.068 & 0.036 & 0.085 & 0.05 & 0.041 & 8.34 & 6.90 & 4.50 \\
\hline \multicolumn{10}{|c|}{ Fertilization treatments: $T$} \\
\hline $\mathbf{T}_{1}$ & 1.28 & 1.25 & 1.27 & 0.91 & 0.90 & 0.91 & 403.4 & 398.5 & 400.9 \\
\hline $\mathbf{T}_{2}$ & 1.50 & 1.42 & 1.46 & 1.10 & 1.08 & 1.09 & 416.4 & 417.5 & 416.9 \\
\hline $\mathbf{T}_{3}$ & 1.16 & 1.16 & 1.16 & 0.85 & 0.81 & 0.83 & 399.5 & 393.2 & 396.3 \\
\hline F. test & $*$ & $*$ & $*$ & $*$ & $*$ & $*$ & $*$ & $*$ & $*$ \\
\hline LSD at 0.05 & 0.036 & 0.081 & 0.042 & 0.059 & 0.041 & 0.034 & 8.37 & 7.80 & 5.42 \\
\hline \multicolumn{10}{|l|}{ Interaction } \\
\hline $\mathbf{V x T}$ & NS & NS & NS & NS & NS & NS & NS & 13.50 & NS \\
\hline
\end{tabular}

$\mathrm{T}_{1}$ : recommended dose of mineral fertilizers i.e. $48 \mathrm{~kg} \mathrm{~N} / \mathrm{ha}+72 \mathrm{~kg} \mathrm{P}_{2} \mathrm{O}_{5} / \mathrm{ha}$ and $57.6 \mathrm{~kg} \mathrm{~K} / \mathrm{O} / \mathrm{ha}$ )

$\mathrm{T}_{2}: 50 \%$ of the recommended dose of N,P and $\mathrm{K}$ i.e. $24 \mathrm{~kg} \mathrm{~N} / \mathrm{ha}+36 \mathrm{~kg} \mathrm{P}_{2} \mathrm{O}_{5} /$ ha and $28.8 \mathrm{~kg} \mathrm{~K} \mathrm{~K}_{2} \mathrm{O} / \mathrm{ha}+$ phosphoric acid( $0.025 \%)$ and potassin (1.8 ppm).

$\mathrm{T}_{3}$ : foliar with phosphoric acid $(0.025 \%)$ and potassin $(1.8 \mathrm{ppm})$.

with those reported by Al Mamun et al. (2012) who found that, wheat fertilization with major nutrients cause increase in chlorophyll content, Ahmed (2017) found that the application with bio fertilizer $+50 \%$ NPK significantly increased total chlorophyll in celery and dill plants, Abdel Naby et al. (2016) results showed another trend for the effect of fertilization on chlorophyll content, where they noticed that increasing NPK fertilization levels from $50 \%$ of the recommended doses $\left(40 \mathrm{~kg} \mathrm{~N}+20 \mathrm{~kg} \mathrm{P}_{2} \mathrm{O}_{5}+40\right.$ $\mathrm{K}_{2} \mathrm{O} /$ fad. $)$ to $100 \%\left(80 \mathrm{~kg} \mathrm{~N}+40 \mathrm{~kg} \mathrm{P}_{2} \mathrm{O}_{5}+80\right.$ $\mathrm{K}_{2} \mathrm{O}$ /fad.), pea plants was accompanied with significant increase in chlorophyll content. Arvind et al. (2018) found that crop growth rate was significantly influenced by foliar application of nutrients. Dry matter production is the sum total effect of overall growth of the plant like plant height and number of branches per plant indicating higher chlorophilic area with improved photosynthetic efficiency of the plants which in turn resulted in higher dry matter accumulation.

\section{Effect of the interaction between cultivars and fertilization treatments}

The results presented in Table 2 show the interaction between soybean cultivars and fertilization treatments significantly affected chlorophyll content during second season only. On the other hand, the effect of this interaction was not significant on CGR in both seasons and combined data. Fig. 1 views that Giza 111 cultivar recorded the maximum chlorophyll content when fertilized by $\mathrm{T}_{2}$ treatment, while, Giza 22 cultivar which received $T_{1}$ fertilizer treatment recorded the minimum values for chlorophyll content in $2^{\text {nd }}$ season. 


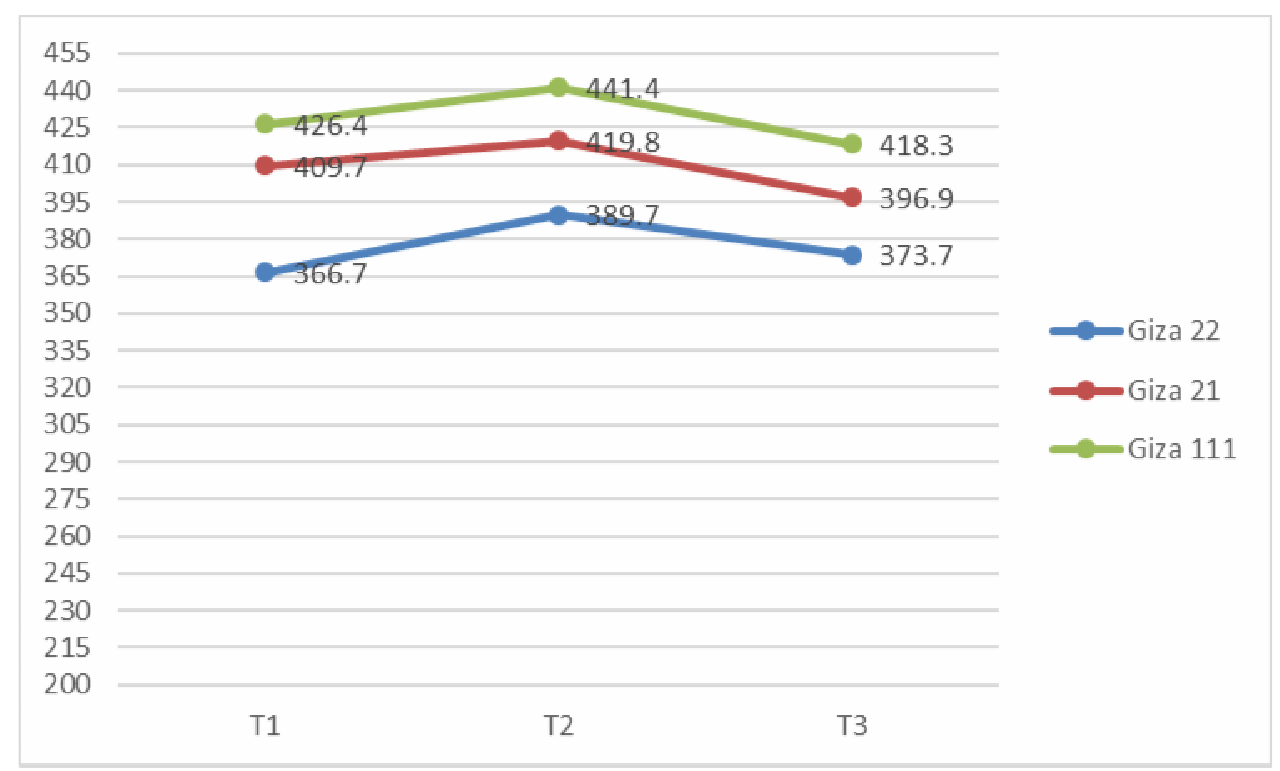

Fig. 1. Chlorophyll content $\left(\mathrm{mg} / \mathrm{m}^{2}\right)$ of soybean for the interaction between cultivars and fertilization treatments in the second season

\section{Yield Components}

Effect of cultivars on plant height, number of branches/plant, number of pods /plant and 100- seed weight

Results in Table 3 reveal that there are significant differences among the three soybean cultivars. Giza $111 \mathrm{cv}$ was significantly higher than other soybean cultivars in each of :number of branches/plant, number of pods/ plant and 100 -seed weight (g).These results are in agreement with those recorded by El-Karamity et al. (2015) where they found that variety Giza 111 surpassed other varieties (Giza 22 and Giza 35 ) in number of branches/plant, seed number/ plant and seed index, Ibrahim (2014) found that the Giza 111 variety surpassed Giza 22 in 100seed weight only. These results may be due to different potentiality in forming branches, pods and seeds of cultivars used in this study, while the increase in seed index is mainly due to ability of cultivars in forming metabolites and its translocation from source to sink which in turn in seed size and mass. On the other hand, plant height showed inversely trend, the tallest soybean plants were recorded by Giza 22 (116.4, 113.7 $\mathrm{cm}$ and $115.1 \mathrm{~cm}$ ) in both seasons and their combine, respectively. The shortest plants were recorded from Giza $21 \mathrm{cv}$. These results are in agreement with those obtained by Husein et al.
(2006), Keyvan and Kobraee (2011) and Ibrahim (2014) who found that Giza 22 plants were slightly taller than Giza 111 cultivar. While, Hemeid (2020) recorded that Giza 35 plants surpassed Giza 22 in number of branches/ plant, number of pods/plant and 100 - seed weight.

Effect of fertilization treatments on plant height, number of branches/plant, number of pods /plant and 100 - seed weight

As for the effect of fertilization, results documented in Table 3 clearly show significant differences in each of plant height, number of branches/plant, number of pods/plant and 100seed weight due to varying fertilization treatments tested in both seasons and combined analysis. It is obvious that the greatest mean values were in favor of $T_{2}$ followed by $T_{1}$ and the lowest value was recorded by $\mathrm{T}_{3}$ treatment in the two seasons and combine analysis. The second treatment $(50 \%$ of mineral fertilizers and spraying with phosphoric acid and potassin) resulted in a significant increase in the studied traits, and exceeded the $\mathrm{T}_{1}$ : (recommended doses of nitrogen, phosphorous and potassium), meaning that the combination between the soil application with $50 \%$ of the recommended amount of fertilizer and spraying with phosphoric acid and potassin morally superior to either foliar or soil addition 
Table 3. Plant height, number of pods/plant, number of branches/plant and 100- seed weight of soybean as affected by soybean cultivars and fertilization treatments during 2015 and 2016 seasons

\begin{tabular}{|c|c|c|c|c|c|c|c|c|c|c|c|c|}
\hline \multirow[t]{2}{*}{ Treatment } & \multicolumn{3}{|c|}{$\begin{array}{l}\text { Plant height } \\
\text { (cm) }\end{array}$} & \multicolumn{3}{|c|}{$\begin{array}{c}\text { No. of } \\
\text { branches/plant }\end{array}$} & \multicolumn{3}{|c|}{$\begin{array}{c}\text { No. of } \\
\text { pods/plant }\end{array}$} & \multicolumn{3}{|c|}{$\begin{array}{c}\text { 100- seed weight } \\
\text { (g) }\end{array}$} \\
\hline & 2015 & 2016 & Comb. & 2015 & 2016 & Comb. & 2015 & 2016 & Comb. & 2015 & 2016 & Comb \\
\hline \multicolumn{13}{|l|}{ Cultivars : V } \\
\hline Giza 111 & 109.6 & 105.7 & 107.7 & 2.86 & 2.73 & 2.82 & 60.89 & 59.89 & 60.41 & 22.36 & 20.84 & 21.61 \\
\hline Giza 21 & 105.6 & 102.9 & 104.2 & 2.16 & 2.06 & 2.11 & 57.78 & 56.52 & 57.16 & 20.51 & 20.02 & 20.29 \\
\hline Giza 22 & 116.4 & 113.7 & 115.1 & 2.00 & 2.02 & 2.03 & 53.24 & 55.08 & 54.17 & 20.71 & 19.06 & 19.92 \\
\hline F. test & $*$ & $*$ & $*$ & $*$ & $*$ & $*$ & $*$ & $*$ & $*$ & $*$ & $*$ & $*$ \\
\hline LSD at0.05 & 7.05 & 9.36 & 4.87 & 0.58 & 0.26 & 0.27 & 4.68 & 2.99 & 2.31 & 1.44 & 0.73 & 0.67 \\
\hline \multicolumn{13}{|c|}{ Fertilization treatments: $T$} \\
\hline$T_{1}$ & 109.4 & 107.9 & 108.7 & 2.32 & 2.17 & 2.27 & 58.46 & 56.97 & 57.72 & 20.92 & 20.16 & 20.58 \\
\hline $\mathbf{T}_{2}$ & 115.6 & 113.3 & 114.5 & 2.66 & 2.74 & 2.72 & 59.13 & 59.50 & 59.32 & 22.65 & 21.56 & 22.12 \\
\hline $\mathbf{T}_{3}$ & 106.6 & 101.0 & 103.8 & 2.03 & 1.90 & 1.98 & 54.32 & 55.02 & 54.69 & 20.01 & 18.21 & 19.12 \\
\hline F.test & $*$ & $*$ & $*$ & $*$ & $*$ & $*$ & $*$ & * & $*$ & $*$ & $*$ & $*$ \\
\hline LSD at0.05 & 3.51 & 4.49 & 2.70 & 0.50 & 0.22 & 0.26 & 2.69 & 2.07 & 1.61 & 0.79 & 0.91 & 0.57 \\
\hline \multicolumn{13}{|l|}{ Interaction } \\
\hline$V \times T$ & NS & NS & NS & 0.28 & NS & NS & NS & NS & NS & NS & NS & NS \\
\hline
\end{tabular}

$\mathrm{T}_{1}$ : recommended dose of mineral fertilizers i.e. $48 \mathrm{~kg} \mathrm{~N} / \mathrm{ha}+72 \mathrm{~kg} \mathrm{P}_{2} \mathrm{O}_{5} / \mathrm{ha}$ and $57.6 \mathrm{~kg} \mathrm{~K} \mathrm{~K}_{2} \mathrm{O} / \mathrm{ha}$ )

$\mathrm{T}_{2}: 50 \%$ of the recommended dose of $\mathrm{N}, \mathrm{P}$ and $\mathrm{K}$ i.e. $24 \mathrm{~kg} \mathrm{~N} / \mathrm{ha}+36 \mathrm{~kg} \mathrm{P}_{2} \mathrm{O}_{5} /$ ha and $28.8 \mathrm{~kg} \mathrm{~K} \mathrm{O}_{2} / \mathrm{ha}+$ phosphoric acid $(0.025 \%)$ and potassin $(1.8 \mathrm{ppm})$.

$\mathrm{T}_{3}$ : foliar with phosphoric acid $(0.025 \%)$ and potassin $(1.8 \mathrm{ppm})$.

treatment only. While, Seadh et al. (2017) found that fertilization by $100 \%$ of the recommended doses surpassed other studied NPK-levels under study and produced the highest means of every one of considered means, followed by using $80 \%$ and then $60 \%$ of the recommended doses. These results can be recognized to that NPK fertilizations is one of the most important nutrients for plant nutrition and enhancing vegetative growth, establishment and yields as well as seed quality. Foliar spray of nutrients is the fastest way to boost up crop growth because the nutrients are available to plants quickly in the initial and critical stages of crop (Jamal et al., 2006).

\section{Effect of the interaction between cultivars and fertilization treatments}

The results in Table 3 show that the interaction relationship between cultivars and fertilization treatments were insignificant for the characteristics of plant height, number of branches/plant, number of pods/plant and 100 - seed weight in both seasons and combined analysis, except number of branches/plant was only significant in the first season.
The significant interactions effect of soybean cultivars and fertilization treatments (Fig. 2) indicates that the highest value of number of branches/plant was obtained by Giza 111 with using $\mathrm{T}_{2}$ fertilization treatment and the lowest value was recorded by Giza 22 cultivar was treated by $\mathrm{T}_{1}$ fertilization treatment. These results are in line with Hussein et al. (2006) who reported significant effect on 100 seed weight in both seasons due to the interaction between soybean cultivars and fertilization treatments.

\section{Yield}

\section{Effect of cultivars on seed, oil and protein yields (ton /ha)}

The results in Table 4 illustrate that there were significant differences between the three cultivars in each of seed, oil and protein yields per ha. Cultivar Giza 111 showed superiority in the traits under study over the other two cultivars, where the highest values were given, followed by the Giza 21, while the cultivar Giza 22 gave the lowest values of the yields. Concerning 


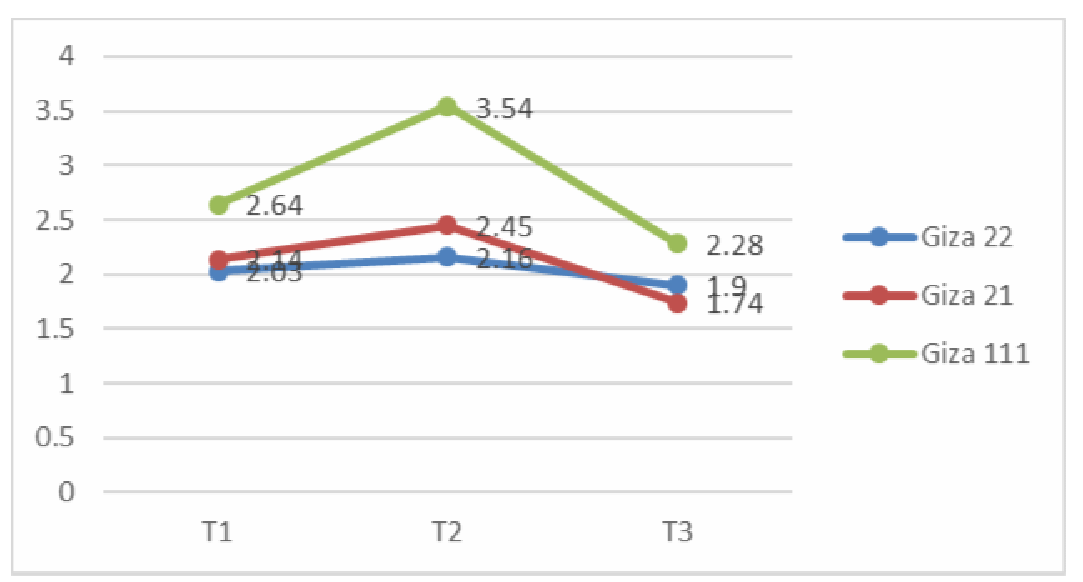

Fig. 2. Number of branches/plant of soybean for the interaction between cultivars and fertilization treatments in the first season

Table 4. Seed, oil and protein yields (ton /ha) of soybean as affected by soybean cultivars and fertilization treatments during 2015 and 2016 seasons

\begin{tabular}{lcccccccccc}
\hline Treatment & \multicolumn{3}{c}{ Seed yield(ton /ha) } & \multicolumn{3}{c}{ Oil yield(ton /ha) } & \multicolumn{3}{c}{ Protein yield (ton /ha) } \\
\cline { 2 - 10 } & $\mathbf{2 0 1 5}$ & $\mathbf{2 0 1 6}$ & Comb. & $\mathbf{2 0 1 5}$ & $\mathbf{2 0 1 6}$ & Comb. & $\mathbf{2 0 1 5}$ & $\mathbf{2 0 1 6}$ & Comb. \\
\hline CultIvars : V & & & & & & & & & \\
Giza 111 & 4.344 & 4.104 & 4.224 & 1.050 & 0.956 & 1.003 & 1.903 & 1.765 & 1.834 \\
Giza 21 & 4.056 & 4.032 & 4.044 & 0.943 & 0.908 & 0.926 & 1.706 & 1.737 & 1.721 \\
Giza 22 & 3.600 & 3.456 & 3.528 & 0.759 & 0.675 & 0.717 & 1.559 & 1.482 & 1.520 \\
F.test & $*$ & $*$ & $*$ & $*$ & $*$ & $*$ & $*$ & $*$ & $*$ \\
LSD at0.05 & 0.21 & 0.06 & 0.09 & 0.11 & 0.03 & 0.08 & 0.120 & 0.026 & 0.11
\end{tabular}

Fertilization treatments: $T$

\begin{tabular}{lccccccccc}
$\mathbf{T}_{1}$ & 3.912 & 3.912 & 3.912 & 0.943 & 0.919 & 0.931 & 1.660 & 1.663 & 1.662 \\
$\mathbf{T}_{\mathbf{2}}$ & 4.296 & 4.056 & 4.176 & 0.979 & 0.887 & 0.933 & 1.864 & 1.767 & 1.815 \\
$\mathbf{T}_{3}$ & 3.792 & 3.624 & 3.696 & 0.831 & 0.733 & 0.782 & 1.644 & 1.554 & 1.599 \\
F.test & $*$ & $*$ & $*$ & $*$ & $*$ & $*$ & $*$ & $*$ & $*$ \\
LSD at0.05 & 0.11 & 0.03 & 0.06 & 0.03 & 0.02 & 0.02 & 0.20 & 0.11 & 0.19 \\
Interaction & & & & & & & & & \\
VxT & $\mathrm{NS}$ & $\mathrm{NS}$ & $\mathrm{NS}$ & $\mathrm{NS}$ & $\mathrm{NS}$ & $\mathrm{NS}$ & $\mathrm{NS}$ & $\mathrm{NS}$ & $\mathrm{NS}$ \\
\hline
\end{tabular}

$\mathrm{T}_{1}$ : recommended dose of mineral fertilizers i.e. $48 \mathrm{~kg} \mathrm{~N} / \mathrm{ha}+72 \mathrm{~kg} \mathrm{P}_{2} \mathrm{O}_{5} / \mathrm{ha}$ and $\left.57.6 \mathrm{~kg} \mathrm{~K} 2 \mathrm{O} / \mathrm{ha}\right)$

$\mathrm{T}_{2}: 50 \%$ of the recommended dose of N,P and $\mathrm{K}$ i.e. $24 \mathrm{~kg} \mathrm{~N} / \mathrm{ha}+36 \mathrm{~kg} \mathrm{P}_{2} \mathrm{O}_{5} /$ ha and $28.8 \mathrm{~kg} \mathrm{~K} 2 \mathrm{O} /$ ha + phosphoric acid( $0.025 \%)$ and potassin (1.8 ppm).

$\mathrm{T}_{3}$ : foliar with phosphoric acid $(0.025 \%)$ and potassin $(1.8 \mathrm{ppm})$. 
to the combined data of seed yield/ha, Giza 111 outyielded the two other ones (Giza 21 and Giza 22 ) by $4.45 \%$ and $19.73 \%$ orderly, while oil yield increased by $8.31 \%$ and $39.89 \%$, as well as, by 6.57 and $20.66 \%$ on protein yield, respectively. The superiority of Giza 111 could be attributed to the genetical constitution as well as its supremacy in number of branches /plant, number of pods / plant and 100 - seed weight (g).Such variatial differences in seed yield were also observed by other workers, among them: Soliman et al. (2015) showed that Giza 111 gave the better values of seed yield by $14.29 \%$ as compared to genotype Toano. Also, Ibrahim (2014) recorded significant variatial variations in seed yield, where Giza 22 surpassed Giza 111 in seed yield, and Hemeid (2020) recorded that Giza $35 \mathrm{cv}$ surpassed Giza 22 in seed yield.

Effect of fertilization treatments on seed, oil and protein yields (ton /ha)

As for fertilization treatments effects, the results in Table 4 clear that the second treatment $\left(\mathrm{T}_{2}\right)$ gave the highest seed, oil and protein yields/ha, where, the combination included the soil addition $(50 \%$ of the recommended fertilization dose) and spraying with phosphoric acid and potassin as another source of phosphorous and potassium elements. The combined of seed yield/ha recorded that $T_{2}$ surpassed the two other ones $\left(\mathrm{T}_{1}\right.$ and $\left.\mathrm{T}_{3}\right)$ by $6.75 \%$ and $12.99 \%$ orderly, while oil yield increased by $0.215 \%$ and $19.31 \%$ on $\mathrm{T}_{1}$ and $\mathrm{T}_{3}$ in (note that the difference between the $\mathrm{T}_{1}$ and $\mathrm{T}_{3}$ treatments in the oil yield was insignificant in combined), as well as, by 9.21 and $13.51 \%$ on protein yield for $T_{1}$ and $T_{3}$ respectively, while, $\mathrm{T}_{3}$ gave the lowest values. Superiorty of $T_{2}$ treatment may be due to its supereminence in number of branches/plant, number of pods/plant and 100 -seed weight, and the role of phosphorus in an increace the suplement of photosynthesis. These results are in line with those obtained by Abdel Naby et al. (2016).

\section{Effect of the interaction between cultivars} and fertilization treatments

Results presented in Table 4 clearly indicated that the interaction effect between cultivars and fertilizer treatments were insignificant differed in all traits.

\section{Quality Traits}

Effect of cultivar on oil, protein, phosphor and potassium percentages in seed and percentages of nitrogen, phosphor and potassium in straw

The results showed significant differences among the three cultivars on all studied traits. In general, the cultivar Giza 111 was superior in these traits in combined analysis (Tables 5 and 6) as compared with other cultivars while, Giza 22 was the lowest in these respect. Such results could be attributed to the genetic differences between cultivars .These results was in agreement with those of Ibrahim (2014) who found that Giza 111 surpassed Giza 22 in protein (\%), but the results are in a reverse trend in seed oil (\%), where Giza 22 surpassed Giza 111, Ibrahim et al.(2017) showed that Giza 111 cultivar gave the better values of the oil and protein as compared to other cultivars Giza 21 and Crawford. While, Hemeid (2020) recorded that Giza $35 \mathrm{cv}$ surpassed Giza 22 on oil (\%).

Effect of fertilization treatments on oil, protein, phosphor and potassium percentages in seed and percentages of nitrogen, phosphor and potassium in straw

Results in Tables 5 and 6 demonestrate that there are significant differences in all the above mentioned traits. This was true in both seasons and combined analysis. From these results, it could be concluded that, $\mathrm{T}_{1}$ treatment, recorded highly means values for seed oil (\%) in both seasons and combined analysis. While, $\mathrm{T}_{2}$ treatment, showed superiority in seed protein content, seed P (\%), seed $\mathrm{K}(\%)$ and ratios of $\mathrm{N}, \mathrm{P}$ and $\mathrm{K}$ in straw in both seasons and the combined analysis. Increasing the content of straw from nutrients is useful in obtaining animal feed with high nutritional value. These results came in the similar point of view with those reported by Eisa et al. (2011) who reveled that there were significant differences between varieties in seed and straw content, Where Giza 22 exceeded over Giza 35 and Giza 111 in seed and straw content from macronutrients $\mathrm{N}, \mathrm{P}$ and $\mathrm{K}(\%)$ and protein yield (Abdel Naby et al., 2016). 
Table 5. Seed oil (\%), Seed protein content, Seed phosphor (\%) and Seed potassium (\%) of soybean as affected by soybean cultivars and fertilization during 2015 and 2016 seasons

\begin{tabular}{|c|c|c|c|c|c|c|c|c|c|c|c|c|}
\hline \multirow{3}{*}{$\begin{array}{l}\text { Treatment } \\
\text { Cultivars : V }\end{array}$} & \multicolumn{3}{|c|}{$\begin{array}{l}\text { Seed oil } \\
(\%)\end{array}$} & \multicolumn{3}{|c|}{ Seed protein content } & \multicolumn{3}{|c|}{$\begin{array}{c}\text { Seed phosphor } \\
(\%)\end{array}$} & \multicolumn{3}{|c|}{$\begin{array}{c}\text { Seed potassium } \\
(\%)\end{array}$} \\
\hline & \multirow[t]{2}{*}{2015} & \multirow[t]{2}{*}{2016} & \multirow[t]{2}{*}{ Comb. } & \multirow[t]{2}{*}{2015} & \multirow[t]{2}{*}{2016} & \multirow[t]{2}{*}{ Comb. } & \multirow[t]{2}{*}{2015} & \multicolumn{2}{|c|}{2016 Comb. } & \multirow[t]{2}{*}{2015} & \multicolumn{2}{|c|}{2016 Comb. } \\
\hline & & & & & & & & & & & & \\
\hline Giza 111 & 24.17 & 23.29 & 23.73 & 43.81 & 43.00 & 43.41 & 0.72 & 0.71 & 0.715 & 2.90 & 2.80 & 2.86 \\
\hline Giza 21 & 23.55 & 22.77 & 23.16 & 42.06 & 43.00 & 42.53 & 0.66 & 0.67 & 0.665 & 2.69 & 2.66 & 2.68 \\
\hline Giza 22 & 21.09 & 19.53 & 20.31 & 43.31 & 42.94 & 43.13 & 0.61 & 0.59 & 0.600 & 2.30 & 2.28 & 2.29 \\
\hline F.test & $*$ & $*$ & $*$ & $*$ & $*$ & $*$ & $*$ & $*$ & $*$ & $*$ & $*$ & $*$ \\
\hline LSD at 0.05 & 1.06 & 0.80 & 0.55 & 0.189 & 0.193 & 0.182 & 0.03 & 0.03 & 0.019 & 0.41 & 0.04 & 0.17 \\
\hline \multicolumn{13}{|c|}{ Fertilization treatments: $T$} \\
\hline $\mathbf{T}_{1}$ & 24.10 & 23.49 & 23.80 & 42.44 & 42.50 & 42.47 & 0.65 & 0.65 & 0.650 & 2.57 & 2.53 & 2.57 \\
\hline $\mathbf{T}_{2}$ & 22.78 & 21.87 & 22.32 & 43.38 & 43.56 & 43.47 & 0.70 & 0.71 & 0.705 & 2.84 & 2.80 & 2.82 \\
\hline $\mathbf{T}_{3}$ & 21.92 & 20.23 & 21.08 & 43.38 & 42.88 & 43.13 & 0.63 & 0.61 & 0.625 & 2.41 & 2.40 & 2.42 \\
\hline F.test & $*$ & $*$ & $*$ & $*$ & $*$ & $*$ & $*$ & $*$ & $*$ & $*$ & $*$ & $*$ \\
\hline LSD at 0.05 & 0.84 & 0.49 & 0.46 & 0.230 & 0.137 & 0.114 & 0.02 & 0.02 & 0.015 & 0.20 & 0.09 & 0.11 \\
\hline \multicolumn{13}{|l|}{ Interaction } \\
\hline $\mathbf{V x T}$ & 1.45 & NS & NS & NS & NS & NS & 0.15 & 0.03 & NS & NS & NS & NS \\
\hline
\end{tabular}

Table 6. Straw nitrogen (\%), straw phosphor (\%) and straw potassium (\%) of soybean as affected by soybean cultivars and fertilization during 2015 and 2016 seasons

\begin{tabular}{|c|c|c|c|c|c|c|c|c|c|}
\hline \multirow[t]{2}{*}{ Treatment } & \multicolumn{3}{|c|}{ Straw nitrogen $(\%)$} & \multicolumn{3}{|c|}{ Straw phosphor (\%) } & \multicolumn{3}{|c|}{ Straw potassium (\%) } \\
\hline & 2015 & 2016 & Comb. & 2015 & 2016 & Comb. & 2015 & 2016 & Comb. \\
\hline \multicolumn{10}{|l|}{ Cultivars : V } \\
\hline Giza 111 & 4.10 & 3.88 & 3.99 & 11.43 & 11.44 & 11.47 & 0.064 & 0.062 & 0.063 \\
\hline Giza 21 & 3.89 & 3.72 & 3.82 & 9.83 & 9.60 & 9.76 & 0.063 & 0.063 & 0.063 \\
\hline Giza 22 & 3.64 & 3.42 & 3.54 & 9.73 & 9.47 & 9.61 & 0.054 & 0.056 & 0.055 \\
\hline F.test & $*$ & $*$ & $*$ & $*$ & $*$ & $*$ & $*$ & $*$ & $*$ \\
\hline LSD at 0.05 & 0.24 & 0.22 & 0.14 & 0.49 & 0.30 & 0.24 & 0.003 & 0.002 & 0.055 \\
\hline \multicolumn{10}{|c|}{ Fertilization treatments: $T$} \\
\hline $\mathbf{T}_{1}$ & 3.84 & 3.66 & 3.75 & 10.07 & 9.94 & 10.03 & 0.061 & 0.060 & 0.061 \\
\hline $\mathbf{T}_{2}$ & 4.08 & 3.93 & 4.01 & 11.37 & 11.40 & 11.39 & 0.064 & 0.065 & 0.064 \\
\hline $\mathbf{T}_{3}$ & 3.71 & 3.43 & 3.59 & 9.56 & 9.17 & 9.39 & 0.055 & 0.056 & 0.056 \\
\hline F.test & $*$ & $*$ & $*$ & $*$ & $*$ & $*$ & $*$ & $*$ & $*$ \\
\hline LSD at 0.05 & 0.198 & 0.105 & 0.106 & 0.283 & 0.416 & 0.256 & 0.002 & 0.003 & 0.002 \\
\hline \multicolumn{10}{|l|}{ Interaction } \\
\hline $\mathbf{V} \times \mathbf{T}$ & NS & 0.184 & NS & NS & NS & NS & NS & NS & NS \\
\hline
\end{tabular}




\section{Effect of the interaction between cultivars and fertilization treatments}

The results in Tables 5 and 6 show the presence of significant interactions between the cultivars and fertilization on oil (\%) in the first season as shown in Fig. 3, phosphorous (\%) in seeds in the $1^{\text {st }}$ season, Fig. (4) and $2^{\text {nd }}$ season (Fig. 5) as well as straw nitrogen (\%) as shown in the second season (Fig. 6).

The results in Fig. 3 show that the highest percentage of oil was obtained from fertilizing Giza $111 \mathrm{cv}$ with either $T_{1}$ or $T_{2}$ treatments without significant differences between them, while the lowest percentage for the Giza $22 \mathrm{cv}$ fertilized with the treatment $T_{3}$.

That is, whether adding $100 \%$ of the recommended dose of $\mathrm{N} \mathrm{P} \mathrm{K}$ or adding only $50 \%$ with spraying with phosphoric acid and potassin were same effect on oil (\%) in seeds oil $(\%)$ in seeds. The characteristics of phosphorous (\%) to seeds in both seasons showed the same trend as shown in Figs. 4 and 5.

The results in Fig. 6 indicated that the highest nitrogen (\%) in straw was obtained when treating Giza 111 cultivar with $50 \%$ of the recommended dose with spraying with phosphoric acid and potassin $\left(\mathrm{T}_{2}\right)$, while the lowest percentage obtained by fertilizing Giza $22 \mathrm{cv}$ with treatment $\mathrm{T}_{3}$.

\section{Simple correlation coefficient between seed yield and its related traits of soybean}

Results recorded in Table 7 indicate the values of simple correlation coefficient between soybean seed yield/ha and the other related characters for combined data.

The results showed that the final seed yield of soybean gave positive and significant associations with each of No. of branches/ plant, No. of pods/plant, 100- seed weight, oil yield, Protein yield and chlorophylle content. However, such yield was positively and insignificantly correlation with: oil (\%) and seed protein content. Likewise, the relationship was not significant and negative with plant height $(\mathrm{cm})$.

Plant height was positive and insignificant correlated with: number of branches/plant, number of pods, 100-seed weight and seed protein content. Meanwhile, negative and insignificant with: oil (\%), oil yield (ton), protein yield (ton) and chlorophylle content.

Also, number of branches/plant was positively and strongly tied with: number of pods/plant, 100-seed weight, Protein yield (ton) and chlorophylle content. Meanwhile, positive and insignificant with: oil (\%), oil yield (ton) and seed protein content.

Withal, number of pods/plant was positive and high significant relevance with each of : oil yield (ton), seed protein content and chlorophylle content. The other relations recorded with such trait were positive and insignificant.

A side from, 100-seed weight recorded positive and strong association with, protein yield (ton). The other relations recorded with such trait were positive and insignificant.

At that, oil percentage was positive and high significant with: oil yield (ton)/fad. While, positive but not significant with, protein yield (ton) and chlorophylle content. But, such trait was negatively and insignificantly correlated with seed protein content.

Furthermore, seed protein content detected negative relation with oil yield (ton) and positive relation with protein yield (ton) and chlorophylle content. But not significant.

Oil yield/ha (ton) reflected positive and significant interrelationship with, protein yield (ton) and high significant with chlorophylle content (Awad et al., 2001; Ash-Shormillesy, 2001).

Ultimately, protein yield (ton) reflected positive and high significant interrelationship with chlorophylle content.

Conclusively, the strong associations obtained between any pairs of the undertaken characters is regarded as a useful indicator to the efficiency of the studied pretreatments in enhancing the yield contributing variables pertaining to improving and maximizing the final seed, oil and protein yields.

\section{Conclusion}

From the obtained results in this study, it could be concluded that, soybean production can be maximized as well as reducing the added amount of fertilizer elements $\mathrm{N}, \mathrm{P}, \mathrm{K}$ to rationalize 


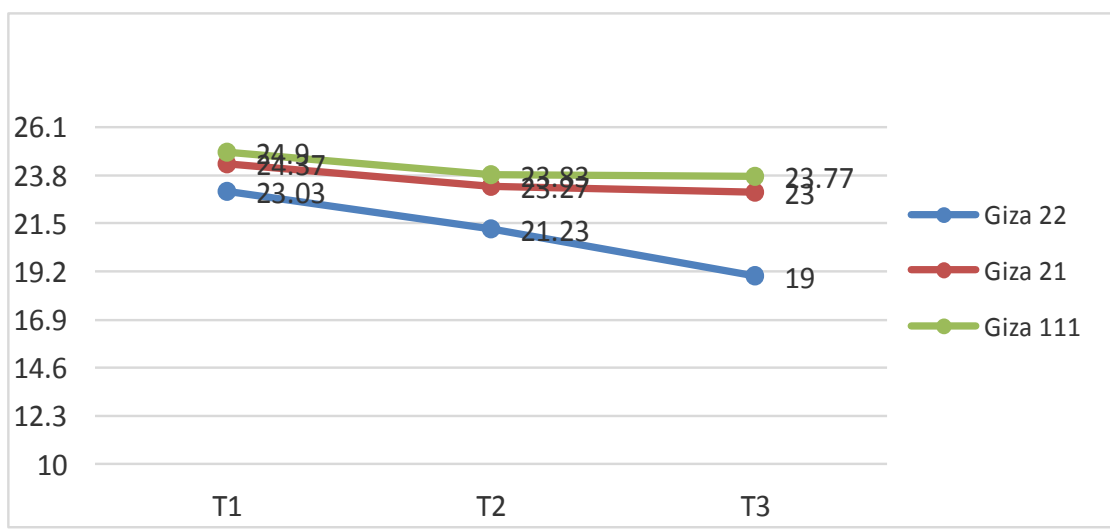

Fig. 3. Seed oil (\%) of soybean for the interaction between cultivars and fertilization treatments in the first season

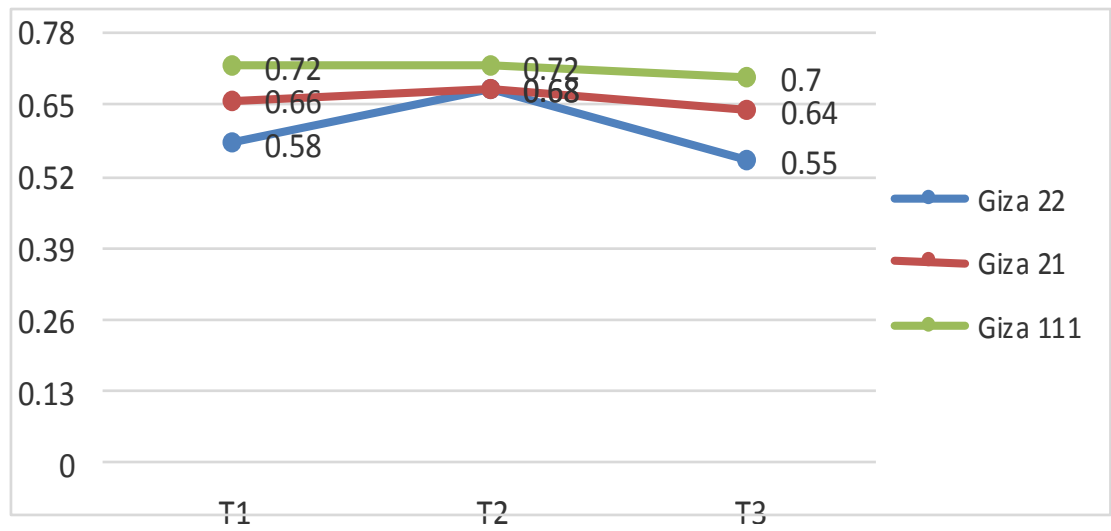

Fig. 4. Seed $P(\%)$ of soybean for the interaction between cultivars and fertilization treatments in the first season

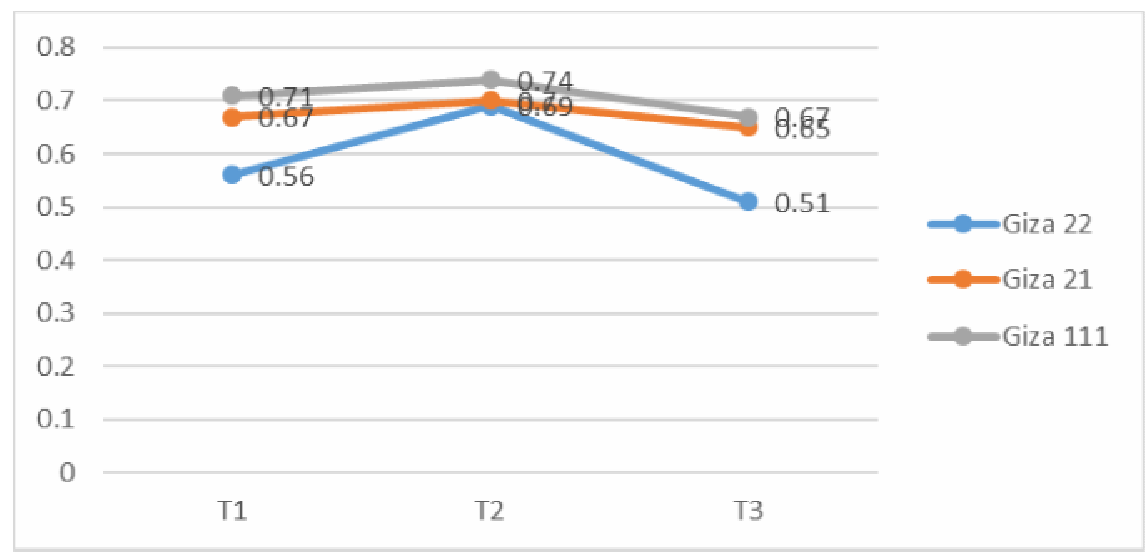

Fig. 5. Seed $P(\%)$ of soybean for the interaction between cultivars and fertilization treatments in the second season 


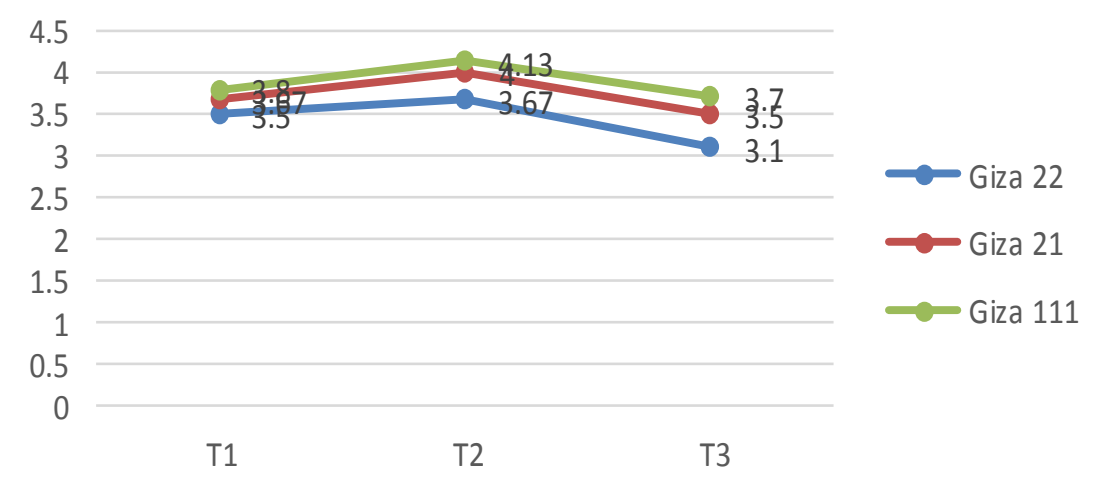

Fig. 6. Straw nitrogen (\%) of soybean for the interaction between cultivars and fertilization treatments in the second season

Table 7. Simple correlation coefficient between seed yield (ton/ha) and other characters of soybean for combined analysis

\begin{tabular}{|c|c|c|c|c|c|c|c|c|c|}
\hline Variable & 1 & 2 & 3 & 4 & 5 & 6 & 7 & 8 & 9 \\
\hline$\overline{\text { Y-Seed yield (ton) }}$ & -0.128 & $30.834^{*}$ & $0.956^{* *}$ & $0.824^{*}$ & 0.749 & 0.179 & $0.954 * *$ & $0.988 * *$ & $0.965^{* *}$ \\
\hline 1- Plant height (cm) & & 0.299 & 0.034 & 0.448 & -0.344 & 0.437 & -0.224 & -0.0673 & -0.250 \\
\hline 2- No.of branches/plant & & & $0.932 * *$ & $0.946^{* *}$ & 0.562 & 0.552 & 0.770 & $0.886^{*}$ & $0.832 * *$ \\
\hline 3- No. of pods/ plant & & & & $0.898 *$ & 0.809 & 0.251 & $0.948 * *$ & $0.959 * *$ & $0.932 * *$ \\
\hline 4- 100- seed weight (g) & & & & & 0.544 & 0.424 & 0.744 & $0.852 *$ & 0.738 \\
\hline 5- Oil (\%) & & & & & & -0.324 & $0.939 * *$ & 0.722 & 0.759 \\
\hline 6- Seed protein content & & & & & & & -0.033 & 0.320 & 0.284 \\
\hline 7- Oil yield (ton) & & & & & & & & $0.915^{*}$ & $0.923 * *$ \\
\hline 8- Protein yield (ton) & & & & & & & & & $0.956^{* *}$ \\
\hline 9- Chlorophylle content & & & & & & & & & - \\
\hline
\end{tabular}

the use of chemical fertilizers in agriculture and reduce their impact effects on soil and water pollution by cultivating Giza $111 \mathrm{cv}$ and fertilizing with $50 \%$ of the recommended dose with foliar spray of phosphoric acid and potassin, under the calcareous soil conditions in Nubaria reagion and similar areas.

\section{REFERENCES}

Abdel Naby, H.M., E.L. El-Fathy, E.L. ElGamily and N.M. Salem (2016). Effect of organic, mineral fertilization and foliar spraying with some biostimulants on growth, yield and chemical composition of Pea. J. Plant Prod., Mansoura Univ., 7 (9): 925- 933.

Ahmed, Z.A. (2017). Effect of NPK and bio fertilization on growth and oil yield of Celery (Apium graveolens L.) and Dill (Anethum graveolens) plants. J. Plant Prod., Mansoura Univ., 8 (2): 247-251.

Al Mamun, M.D.N., M.D. Sainur Rahman, N.M. Jahanir, M.S. Moula and K.N. Islam (2012). Effect of phosphate rock on the growth and yield of wheat (Triticum 
aestivum L.) under old Brahmaputra Floodplain soils. Agric., 10 (1): 31-37.

AOAC (1980). Association of Official Agricultural Chemists Official Methods of Analysis, $13^{\text {th }} \mathrm{Ed}$, Washington, DC, USA

Arvind, K.S., C.S. Singh, A.K. Singh and S. Karamakar (2018). Soybean productivity as influenced by foliar application of nutrients. J. Pharmacognosy and phytochemistry, SPI: 413-415.

Ash-Shormillesy, S.M.A.I. (2001). Effect of seeding rate and fertilization on yield and quality of flax. Ph.D. Thesis, Fac. Agric., Zagazig Univ., Egypt.

Awad, A., A.M. Abdel-Wahab, H.M. AbdelMottaleb and M.M. Hussien (2001). Effect of seeding rate and nitrogen fertilizer levels on flax. 4- Straw, seed and oil yields correlation and path analysis study. Zagazig J. Agric. Res., 28 (2): 251-260.

Devlin, R.M. and F.H. Witham (1983). Plant Physiology. Boston, Willard press $4^{\text {th }} \mathrm{Ed}$.

Diacono M., P. Rubino and F. Montemurro (2013). Precision nitrogen management of wheat; a Rev. Agric. Sustainable Develop., 33 (1): 219-241.

Eisa, S.A.I., B.T. Mohamed and A.M. Mohamed (2011). Amendment of soil fertility and augmentation of the quantity and quality of soybean crop by using phosphorus and micronutrients. Int. J. Acad. Res., 3 (2): III.

El Haggan, E.A. and M.E. Mekkei (2014). Productivity of some soybean (Glycine max (L.) Merr.) cultivars under different plant densities. Egypt. J. Plant Breed., 18 (3): 379-388

El-Karamity, A.E., M.A. Salem and A.A. Mohamed (2015). Response of some soybean cultivars bacterial inoculation combined with $\mathrm{N}$ fertilization. Minia J. Agric. Res. and Develop., 35 ( 2): 195-205

Gomez, K.A. and A.A. Gomez (1984). Statistical Procedures for Agricultural Research. A wiley-Int. Sci. Publication, John Wiley and Sons, Inc. New York, USA.

Hassaan, M.A. and A.M. Bughdady (2018). Response of some sesame cultivars
(Sesamum indicum L.) to bio and organic fertilizers under Toshka conditions. J. Plant Production, Mansoura Univ., 9 (11):931- 938

Hemeid, M.M. (2020). Productivity and oil content of soybean as affected by potassium fertilizer rate, time and method of application. Asian J. Crop Sci., 12 (1): 19-25.

Hussein, T.F., G.A. Darweish and M.M. Rattiba (2006). Effect of planting dates on growth, yield and quality of some soybean cultivars at Al-Gabal Al-Akhadararea- Libya. J. Agric. Sci. Mansoura Univ., 31 (2):587-594.

Hussein, M.S. (1995). Response of coriander and dill to different nitrogen sources. Egypt. J. Hort., 22 (1): 1-10.

Ibrahim, M.E., T.A. Elewa and D.G. Mona (2017). Response of soybean cultivars to weed control treatments. Agric. Eng. Int.: CIGR J. Open access at http://www.cigrjournal.org.

Ibrahim, M.M. (2014). Response of two soybean cultivars to plant density and phosphorus fertilization. Minia J. Agric. Res. and Develop. 34 (3): 369-383

Jackson, M.L. (1967). Soil Chemical Analysis. Prentice Hall, Inc. Englewood Cliffs. NJ, 498

Jamal, Z., M. Hamayun, N. Ahmad and M.F. Chaudhary (2006). Effect of soil and foliar application of different concentrations of NPK and foliar application of $\left(\mathrm{NH}_{4}\right)_{2} \mathrm{SO}_{4}$ on different parameters in wheat. J. Agron., 5 (2): 25- 56.

Keyvan, S. and S. Kobraee (2011). Soybean agronomic responses to plant density. Ann. Biol. Res., 2 (4):168-173.

Klute, A. (1986). Methods of analysis. Part I, Soil Physical properties. ASA and SSSA, Madison, WI.

Monje, O.A. and B. Bugbee (1992). Inherent limitation of nondestructive chlorophyll meters- A comparison of types meters. Hort. Sci., 27: 69-71

Murphy, J. and J.P. Riley (1962). A modified single solution method for determination of phosphate in natural waters. Anal. Chim. Acta., 27: 31-36. 
Piccinin, G.G., A.L. Braccini, L.G.M. Dan, C.A. Scapim, T.T. Ricci and G.L. Bazo (2013). Efficiency of seed inoculation with Azospirillum bra silence on agronomic characteristics and yield of wheat. Indus. Crops and Prod., 43: 393-397.

Savani, V.N., M.R. Vaioshnav, P.R. Vaishnav and V.B. Darji (1995). Statistical estimation of relative changes in $\mathrm{P}$ content with different levels of applied phosphorus in groundnut. J. Gujarat Agric. Univ., 21: 119-123.

Seadh, S.E., W.A.E. Abido, A.N. Abd El-Al and Z.A.A. Ibrahim (2017). Effect of NPK levels on productivity and seed quality of some groundnut genotypes under newly reclaimed sandy soils conditions. J. Plant Prod., Mansoura Univ., 8 (5): 605 - 609.

Soliman, I.E., A.R. Morsi and A.E. Khaffagy (2015). Effect of competitive abilities of some soybean genotypes, plant densities and weed control treatments on soybean (Glycine $\max L$. Merr) and its associated weeds. J. Plant Prod., 6 (8): 1413-1429.

Steel, R.G.D. and J.H. Torrie (1980). Principles and Procedures of Statistics. A Biometrical Approach, Second Edit. Mc Grow- Hill Book Co., New York.

Watson, D.J. (1952). The physiological basis of variation in yield, Advanc. Agron., 4: 101-145.

\section{تأثير الرش والتسميل الارضي على إنتاجية وجودة بعض أصناف فول الصويا تحت ظروف الأراضي الجيرية 'اتجي سمير محمد ربيع أبو زهره' ـ ماري عريان ناثد' ـ سهام محمد محمد' ـ سلوى محمد اليماني الثرملسي'

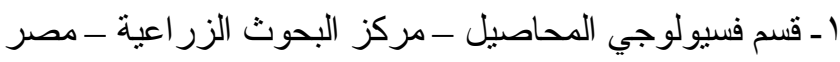$$
\text { r ـ قسم المحاصيل ـ كلية الزر اعة - جامعة الزقازيق - مصر }
$$

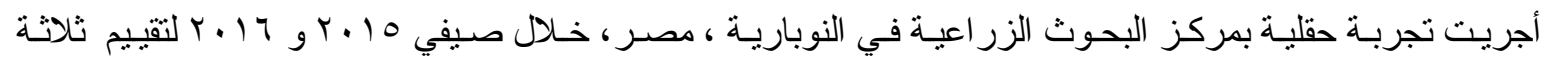

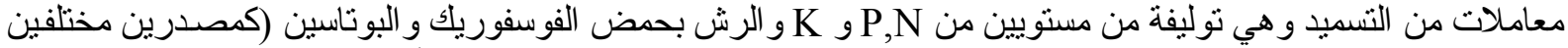

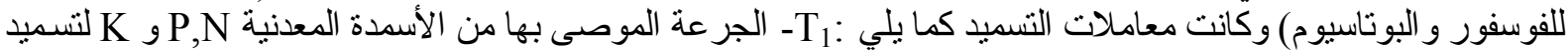

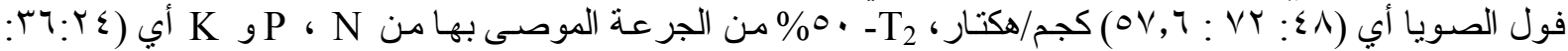

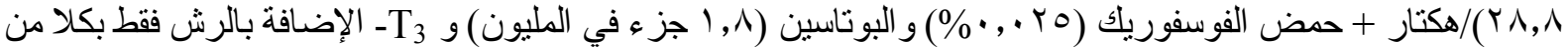

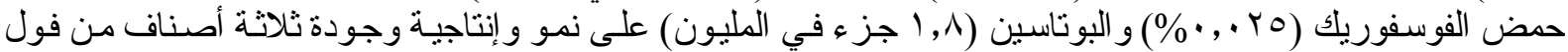

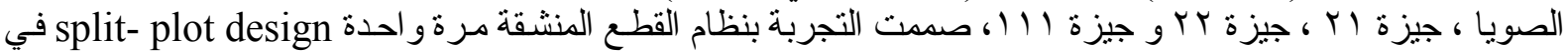

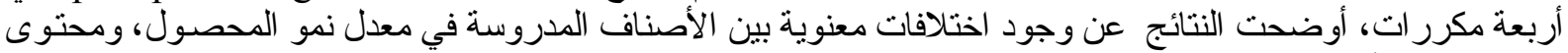

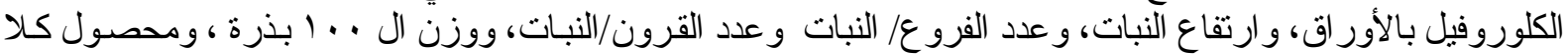

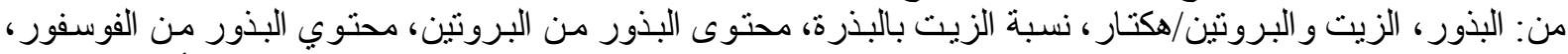

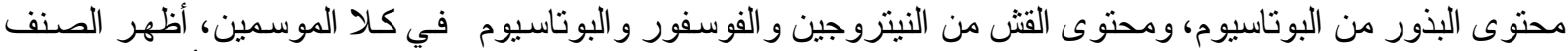

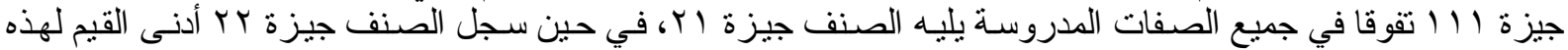

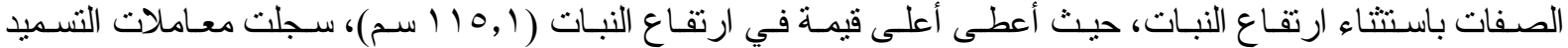

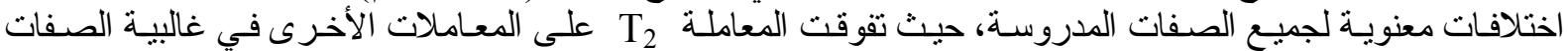

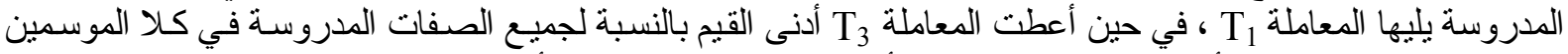

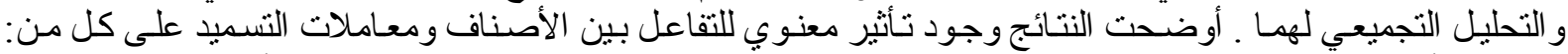

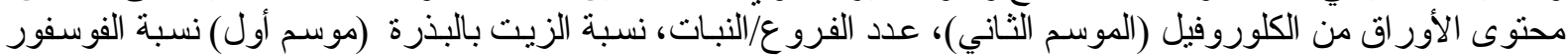

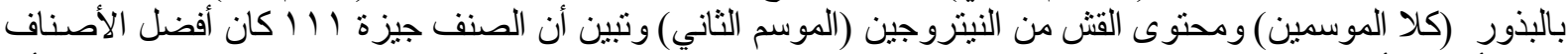

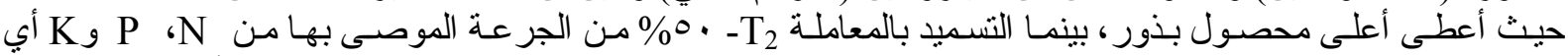

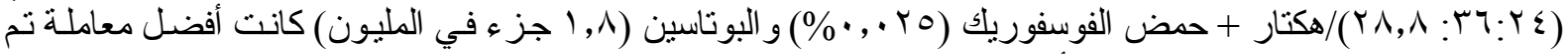

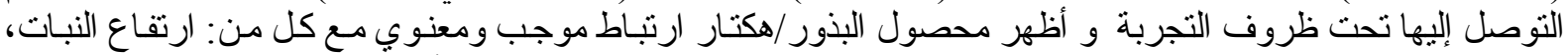
عدد القرون/ نبات، وزن ال . ا بذرة، محصول الزيت، محصول البروتين ومحتوي الأور اق من الكلوروفيل. 